\title{
The Contemporary Yemen Unity (1990-2019) the Foregrounds and Aftermaths, (Historical Perspective)
}

By Dr. Mahmmoud Al-Jbarat

Al-Balqa Applied University

Abstract- The Yemen Unity has always been and will remain a vital and crucial issue for Yemen, the Yemeni people, and the Arabian Peninsula's present and future generations. It corresponds to its entities political future, the Arabian Peninsula's strategic position, wealth, regional and international role, the effects of such unity "or division" upon the region's peoples and the overall reflection on the problems and risks which threaten the Arab World and, as a consequence, the region, and the world as a whole.

This study tries, in the light of such importance, to present an objective summary over the development of this unity, indicating the contributing factors and the division reasons through a historical perspective which highlights the events and tries to submit an analysis over the modern Yemeni Unity path which constitutes a point of concern for the contemporary Arab thought.

The study hypothesizes that the Riyadh Agreement has constituted a turning point and focalization climax of the regional parties' attitude towards the Yemeni unity and that the development of subsequent international approaches, in this concern, will drastically affect the Yemeni future and unity.

Keywords: the yemen contemporary history, yemen unity, yemen crisis.

GJHSS-D Classification: FOR Code: 210399p

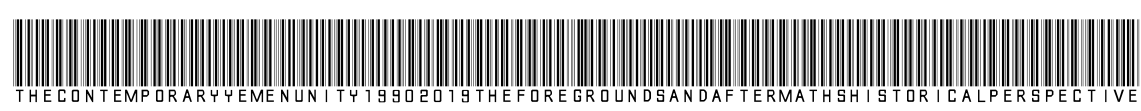

Strictly as per the compliance and regulations of:

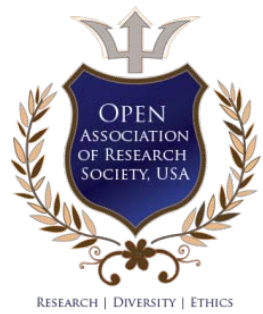

(C) 2021. Dr. Mahmmoud Al-Jbarat. This is a research/review paper, distributed under the terms of the Creative Commons Attribution-Noncommercial 3.0 Unported License http://creativecommons.org/licenses/by-nc/3.0/), permitting all non-commercial use, distribution, and reproduction in any medium, provided the original work is properly cited. 


\title{
The Contemporary Yemen Unity (1990-2019) the Foregrounds and Aftermaths, (Historical Perspective)
}

\author{
Dr. Mahmmoud Al-Jbarat
}

Abstract-The Yemen Unity has always been and will remain a vital and crucial issue for Yemen, the Yemeni people, and the Arabian Peninsula's present and future generations. It corresponds to its entities political future, the Arabian Peninsula's strategic position, wealth, regional and international role, the effects of such unity "or division" upon the region's peoples and the overall reflection on the problems and risks which threaten the Arab World and, as a consequence, the region, and the world as a whole.

This study tries, in the light of such importance, to present an objective summary over the development of this unity, indicating the contributing factors and the division reasons through a historical perspective which highlights the events and tries to submit an analysis over the modern Yemeni Unity path which constitutes a point of concern for the contemporary Arab thought.

The study hypothesizes that the Riyadh Agreement has constituted a turning point and focalization climax of the regional parties' attitude towards the Yemeni unity and that the development of subsequent international approaches, in this concern, will drastically affect the Yemeni future and unity.

Keywords: the yemen contemporary history, yemen unity, yemen crisis.

\section{INTRODUCTION}

E ven though Yemen has always been one and the undivided territorial, geographic, cultural, and civilizational unit, its political unity, as one unified central state was successful only in two relatively long periods, the first was in the ancient ages during the Sabaean state age, between 9BC-6AC, while the second was realized during the Islamic ages at the era of Prophet Mohammad (Peace be upon him) the Kaliphs, Umayyad State and some periods of Abbasid state. The de-centralized model was the dominant one during Yemen's political history.

Yemen was, before and after these stages, divided into politically conflicted entities with overlapping control and sovereignty whereby the state control over Yemen's different territories increases or shrinks due to conflicting mini local states or greedy foreign states (Homerite Kingdom, Habshis, Persians, Ottomans, Great Britain, the Soviet Union, and the USA), whereas the Yemeni social and cultural structure has remained intact.

Author: Associated Professor of Modern and Contemporary History, Al-Balqa Applied University, Jordan.e-mail: aljbarat@bau.edu.jo
Yemen has been divided into two divides, given the political dismantling of the contemporary Arab history after the colonization, with two distinct societies about the social and economic structure, political thought development, awareness level, communication nature, internal political relations in each division and the external relations with the other part from one side and the regional and world community from another. The national state in both divided has not acknowledged this trans-political identity, and the Yemenis awareness of their unified cultural identity has remained intact.

When the Yemeni political merger became a unified state in the year (1990), the Arab world was facing political break up and division, which increased further during and after that unity, causing adverse effects upon each country's political and social stability, authority and sovereignty. Therefore, the advocates of (Pan-Arabism), continued to consider Yemen's unity a living model that can achieve comprehensive Arab unification, from one part, and as a hope to preserve, maintain, and repeat it successfully from another.

This research paper tries to discuss the foregrounds of Yemen's modern unity, the achievement manner, what are its instruments, necessities, and success factors on different political, social, and economic levels, and the effect of the unified state's institutions and structures performance, with an attempt to answer some questions, such as, among other things: Did the unity state achieve sustainable political stability, social and economic development?

Did the unity state contribute to a fair distribution of the development gains? How the unity state utilized both divisions' economic and social factors of growth and what are the benefits obtained under the unity and hopes which the unity state didn't realize?

The paper also reviews the role played by the Yemeni political parties towards the unity or the call for secession, the democratic process at the unity state, and whether the Yemeni governments were legitimate or if the state could override the merged unity's obstacles, such as inter- ethnic conflict and sectarianism, corruption, personal aspirations and influence centers conflict. It also discusses the role and attitude of the regional and international powers towards this unity in its different stages. 
Furthermore, it reviews the contemporary Yemeni crisis (2011-2019) and its effects upon the unity state, the current challenges facing Yemen's unification and the potential aftermaths under the current conditions in the country and the region and the factors affecting the modern unity, especially the regional and international attitude, political merger question and who currently control the deep state in Yemen.

This paper is an attempt to put forward an objective concise over the development of this unity, indicating the factors which contributed to its creation and the division reasons from a historical perspective, which analyses the events and tries to present an analysis about the modern unity of Yemen which constitutes an ongoing concern for the modern Arab thought.

Yemen has passed over short or medium periods whereby, it was ruled by more than one political system and subjected to more than one political system at a time.

The political systems have, for ages, been trying to control the whole or parts of Yemen, in contrast, sometimes, the central state of Yemen tries to control areas outside the Yemeni territories, as was the case during the Sabaean and Homelite dynasties. Many conflicting states or emirates have also tried to control Yemen's controversial areas, as was the case during the era of Ma'een, Kotban, Hadramaut, and Osan.

\section{il. Yemen During Central Islamic State}

Yemen's unity was dismantled during Habshis rule when they entered the state in the year (525) than during Persian Rule, in contrast it unified during Prophet Mohammad (Peace be upon him) era and the Caliphs (620-661) as it affiliated to the Islamic State Capital, AlMadina Al- Monawara, then Damascus, capital of Umayyad State (661-753) with some disturbances, instability and Yemeni opposition movements to the Umayyad State Authority. Then it affiliated to Baghdad, capital of Abbasid State, until the year (819) when Caliph Al-Mamoun took power, as Mohammad Bin Abdullah Bin Zeyad established an independent emirate in Yemen, which extended from Hili Bin Yakob City (South of Konfidha on Tahama Beach) to the north until Aden, Hadramaut, Al- Shahar and Al-Mohra to the south, then Bin Zeyad chose Zabid as capital. Sa'dah was not under the state's control, in contrast, Sana' became the capital for the first Zaidi State during the $19^{\text {th }}$ Century after secession from Abbasid State and became under the influence of Imam Al-Hadi since the year (897). Al-Safar Hawali clan has, since the year (872) and for more than a century and a half, controlled an area situated between Sa'dah and Al-Jind, with extensions or shrinks, according to their power or opponents power, in contrast, Ali Bin Al-Fadhl Al-Qormiti controlled Sana' until the year (915). The conflicts have continued between Al-Jafar, Zaidi emirate, and advocates of Ismaili doctrine, without unified or fixed boundaries among such mini-states and emirates. Different mini-states and emirates came into existence, such as (Al-Najah in Tohama region 11013-1661) and Al-Salihi State (1038-1138), which controlled the whole of Yemen until the Hejaz region. Yemen has partitioned again between Zaidi Imamate at Sa'dah area, Al- Hatem Al-Hamadani in Sana', Al-Zorei in Aden, Al-Mahdi Emirate in Tohama and Al-Wahas north of Tohama. Amid such partition and conflicting local mini-states, the Ayyubid entered to govern Yemen for half a century (1174-1229). The controlled nearly the whole country, except for some areas of Al-Zarieia State. However, some of their representatives fought each other and became loyal to Imam Abdallah Bin Hamza Al-Zaidi in Sa'adah. Then the Imam subsequently controlled Sana' in (1214), whereas the last Ayyubi ruler (Nouraldin Omar Bin Rasol) established the Rasulid State, independently from the Ayyubi. His control extended from the Hejaz region to Hadramaut in (1250). Yemen has witnessed a scientific, literary, and architectural prosperity period, supported by its unity and stability during the Ayyubi and Rasulid eras for two and a quarter centuries until the year (1443).

\section{ili. The Yemeni Mini States}

The Tahirid State, with its capital Al-Miqranah, then Rada'a and Sana' was reinforced when the Rasulid State became weak, so it extended north as from (1454) to Ta'ez, then Dhamar, Tohama, Sana' and controlled Hashid Land. Its influence extended to Yemeni territory in (1506). However, Mamluks control over Kamran, Zabid, Ta'ez, and Sana' has eliminated the Tahirid rule over Yemen in (1517), so, Yemen became under the power of Mamluks, Imam Sharafuldin Al-Zaidi and his son Al- Motaher in the north, as they chased the Tahririds until Area, then they resisted Mamluks and Ottomans.

No Yemeni Sunni Muslim has ruled North Yemen or any part thereof since that time. Also, Sana' wasn't a Sunni Capital for Yemen until the revolution (1962) (Marmia, January 2008, page 3).

Also, no Zaidi Shiite Imam has unified the whole of Yemen in one centralized state, as they controlled only the north since Imam Al-Hadi era in (897) until Imam Al-Motawakel Ismail (1644-1676) the latter extended his rule to south Yemen and controlled Hadramout, while his Al-Qasem successors partially ruled some areas in the south and north Yemen. The Zaidi area's unity was disputed several times because of the Imams' conflicts over religious ruling inside the Alawi house and among the Imams and their opponents in other Yemeni mini-states and emirates, thus leading to a state of instability. 
IV. The OtTomans, Heirs of Islamic Central State

The Ottomans have ruled Yemen in two eras, the second began in (1869) when the northern province became part of the Ottoman State, in contrast Britain has controlled Aden since (1839), and continued and reinforced its control with the Yemeni coast sultanates until the end of World War (1). The Zaidi Imams continued to control north Yemen due to the political and military attitude differences between both parties, during the war, as Britain was with the allied forces, in contrast Imam Ali remained loyal to the Ottoman State since their Da'an accord in (1911) till the end of World War (1), as he managed to establish Mutawakkilite Kingdom of Yemen. He continued to rule north Yemen and tried to expand southwards and westward, but he was opposed by Britain, Al-Idrisi and the Saudis. Britain continuously confirmed that it didn't mind to sharing Arabian peninsula territories with France and Italy if they acknowledge its influence and special status in the Arabian peninsula (Fisher, July 1997).

The conflict between Zaidi imamate and Al-Idrisi from one part and Saudi Arabia and Zaidi Imamate from another continued until Al-Idrisi controlled Tihamah and Yemen marked its boundaries with Saudi Arabia through the Jeddah convention in (1934) to ease the tension between both countries. Saudi Arabia, which adopts the Hanbali Sunni doctrine concluded a close alliance with the Zaidi Shiite imamate, as it supported Imam Zaidi at times of danger, especially during the coup attempt against Imam Yahia in (1948) and a coup attempt against his successor Imam Ahmad in (1955) and (1962) revolution against Imam Al-Bader.

\section{The Yemeni Arab Republic}

The Zaidi imamate came to an end in north Yemen with the success of the (1962) revolution, so the Zaidi doctrine lost its institutional framework, some Zaidis embraced the Sunni belief and worked upon Islamic jurisprudence heritage, while few others tried to cut their relations with the Zaidi identity (Berk, January 2008, P. 192).

Six years later, Britain ended its control over south Yemen, at the same time the discrepancies remained apparent between both divides, as the political power in the north was individual, theocratic, Zaidi Shiite doctrine and tribal, with (141) tribes, the most distinguished of which was Hashid and Bakil tribes in north Yemen, with (40) tribes of which adhering to the Zaidi doctrine and living in the heights, in contrast, the Sunni Shafil doctrine is dominant in (27) tribes in Tihamah. The closed social attitude is a characteristic of the Yemeni tribes (Jirasimov, 1982, P. 30) but they hinder modernization and development and live in an agricultural and pastoral society with a primitive economic structure. South Yemen was ruled by political parties with lesser tribal influence as a social system and a more developed economy than to the north.

The discrepancy remained apparent between the political systems of both divides. In the north, which was recognized by Saudi Arabia, the political tendency was favoring and generally detente to the west economically, especially to the Federal Republic of Germany. At the same time, the foreign investments were also welcome, whereas the system in the south followed the scientific socialism, the first of its kind in the Arab world, liaised with the eastern camp, cut its relation with the western powers and nationalized the public projects. The doubts in both systems have led to mutual polarization of the other divide's opposition forces.

The interaction models in both divides after Yemen's independence have focused on several forms, beginning with armed conflicts, then an accord and a rapprochement, freezing and armed clashes again, then returning to discussion, and meeting.

Each party alleges that the armed conflict was due to the other party's greed in some of its territory, so, north Yemen has, after the 1962 revolution, become an axle for political contradiction in the Arab peninsula (Haliday, 2008, P. 133).

The first unity accord between both divisions took place in Ta'izz on 25 and 26/11/1970, whereby they concluded a federal union. However, armed clashes erupted between both divides in February (1972) over Harib (90 Km South East of Ma'rib). North Yemen called for the intervention of the Arab League, whereas the south considered it as Arabization and Globalization of the conflict.

It also accused the north of being a follower of colonization when the US secretary of State (William Rogers) paid a visit to the region.

The Arab reclamation committee, established by the Arab League in October (1972) recommended to implementing the union agreement, which included forming a unified political organization, consisting of the categories elected by the people, which is the stockholder of the revolution to work against backwardness and heritage of imamate and colonial eras (Abu Taleb, January, 1994, P. 84).

I noticed that this accord tried to merge both divides demands in a fragile conciliatory text, to the effect that Islam is the state's religion and the source for legislation and to endeavor to achieve socialism based upon Islamic Arab heritage.

The relations normalized between both divides despite opposition by several organizations that abstained from supporting the accord. The unity talks continued until the north allegation following the assassination of one of its tribal leaders (Sheikh Mohammad Ali Othman) was assassinated in Ta'izz on 03/05/1974 so the negotiations came to a halt. The north had the tendency to achieve unity by force. Still the 
corrective movement, led by lieutenant colonel Ibrahim Al-Hamdi, contributed to the détente of the relations with the south, in addition to many other developments, such as the attitude of President Salim Rabie Ali (193526/6/1978) when he called the national leaders to achieve the unity, let alone Israel's ambitions of Bab el Mandab strait. Therefore, both presidents Ibrahim AlHamdi and Salem Rabie Ali met in a summit meeting and agreed to form a joint council to follow up the work of the different joint committees at various fields, coordinate the foreign policy and coordinate the cooperation in the different industrial and agricultural development fields. However, Al-Hamdi's assassination, one day before heading to Aden, delayed the unity project.

President Mohammad Hussein Al-Ghashmi (1941-24/06/1978) assumed power in South Yemen for (9) months, but he fell victim to an assassination attempt, so, a conflict appeared to surface between the moderate wing, led by Salim Rabie Ali, and the extremist one, led by Abdelfattah Ismail (1939-13/01/1986), so the latter sentenced the former to death in February (1978). Then, the armed conflict escalated in the south, and the previous differences hindered a rapprochement between both divides due to an armed conflict between them.

The Kingdom of Saudi Arabia didn't trust the rapprochement and unity of both divides, as it supplied the north with weapons to face the south, upon demand by the United States and was observing the north forces which expressed their dissatisfaction about this matter (Kotsinoveski, January, 2008, P. 79).

The unity projects during the years (1972-1979) have focused on the political and constitutional framework, then the social aspects (Abu Taleb, January 1994, P. 116).

\section{Vi. Unity During President Ali Abdallah SAlEh ERA}

The Iranian revolution in early (1979) and its effects on the Arab political system and US interests in the region, as it lost its most important base in the Middle East to protect its interest in the Arabian peninsula, has contributed to reconsider the region's issues, including the Yemeni unification, regionally and internationally, so the unity hastened.

On 30/03/1979, President Saleh and President Abdelfattah Ismail signed the Kuwait convention, which asserted the Cairo agreement in (1972), the Tripoli declaration, and practical and constitutional steps to declare the unity state constitution within (6) months.

Then, on 13/06/1980, President Saleh signed an agreement with President Ali Nasser Mohammad, to cooperate to achieve security and stability, return of Yemeni citizens to their houses, abstaining from supporting any aggressive activity, re-positioning of the armed forces, and putting a plan to defend the Yemeni territory. A periodical meting took place between both Presidents, followed by a summit meeting in Kuwait on 23/09/1981 to solve the military confrontation between the national front forces, which oppose the north divide and supported by the south to liquidate the differences between them.

Then Sana's agreement occurred on $03 / 12 / 1981$. Both sides agreed to form unity bodies, such as the Yemeni Council, which includes the president of both divides, a secretariat for the council, and a ministerial committee. Then, an accord at the end of (1981) has put forward a merger constitution draft. Then the United Yemen Republic was declared in Aden in early (1982) as being a socialist state which adopts Islam as an official religion.

The year (1983) has witnessed the signature of many accords, which reached their climax by holding a session for the superior Yemeni Council in Sana' to achieve the constitution, with an accord over the unity steps. Unified pedagogic curricula were agreed upon by both divides in early (1984). The superior Yemeni Council continued to hold periodical meetings each (6) months. During the summit meetings in Aden and Ta'izz in (1985) the key issue facing the unity was dealt with, i.e., the oil investment region in Ma'rib and Shabwah, without Arab mediation.

However, the bloody events in Aden early (1986) terminated the era of President Ali Nasser Mohammad. In an attempt to contain the consequences, a summit meeting took place between President Saleh and President Ali Salem Al-Beidh (1939-) In May (1988) they reached an accord to excavate oil. After oil discovery, it seemed that Yemen would no longer depend upon the Saudi financial support and to begin to play a confirmed role in the region. (Gause III, 1988).

The unity talks resumed among pressing internal and international conditions on both North South Yemen. (Rojeh, January, 2008, P. 123- 158). Transportation between both divides became easier as both ruling parties agreed to continue their works with acknowledgement of the political multi-party system. Most Yemeni cities witnessed marches to demand unity. So, the President of both divides responded during a summit meeting in Aden on 30/11/1989 by agreeing to acknowledge the constitution project, submit it to the legislative power, make a popular referendum and settle the unity declaration on 22/05/1990, without making a popular referendum during the transitional period. These steps occurred after summit meetings between President Saleh, who is president of the Yemeni Arab Republic, and General Secretary of the Yemeni socialist party, Ali Salem Al-Beidh, President of the Popular Democratic Republic of Yemen, so that unity dream became a reality. 
Both systems constitution confirmed the belief and necessity of the unity, but there were differences of how to materialize it despite the insistence not to abandon. The achievements are already realized by each divide, given the heritage of past partition and armed conflicts. The unity state, with its rising multi political system, even "authoritarian" (Philips 2007, P. 5) elected parliament, free press, and population, the biggest in Arabian Peninsula, has constituted a pioneering attempt in the region, so it may have disturbed the regional countries which adopt the heritage and theocratic system and which disregard the democracy and multi-party system.

With the establishment of the Sunni reformist movement, backed by Saudi Arabia, the activity of the Yemeni Congregation for reform party under the unity state and the creation, in a tolerant political environment, of a competing current which reaffirmed the Zaidi Shiite identity, the political merger process was violently Shaken lesser than (4) years after the eruption of a conflict between categories having acquired and historically inherent political powers and presence of secessionist political and social forces (Al-Sweidi 1995, P. 10). The system was merged but not coherent and that the Yemenis in the south initially thought that they are equal partners, but later discovered the contrary, as it became evident to them that the people in the north are a closed tribal institution.

The unity state suffered from backwardness, tribalism, sectarianism, social and economic differences, and religious extremism. These, along with the aftermath of the $2^{\text {nd }}$ Gulf War and the collapse of the Soviet Union, have led to a civil war in Yemen in (1994) (Hidson, 1995, P. 21- 37).

The southern elite endeavored to change the $22^{\text {nd }}$ May unity accord text through the pledge and accord document, signed in the Jordanian Capital, Amman, in February (1994). It included dividing the state into new administrative units, granting them powers in the form of the autonomous region and the holding of a federal system in Yemen to recognize the political and social actors of a peaceful revolution within a political contract logic, never seen in Arabia before (Rojeh, January 2008, P. 146-147) in addition to amending the executive authority's missions and powers and other articles to lessen the centralism and northern domination. However, it later became evident that it dealt with the unity state crisis by balancing two projects, i.e., the majority democracy project, adopted by the north, and the conciliatory democracy project, based upon multiparty system and power-sharing, adopted by the south to build a merger unity state (AlSharjubi, July 2011).

The kingdom of Saudi Arabia supported the Vice President (Al-Beidh) about the independence of the south and the possibility to cancel the unity. It also exploited the circumstances to sign an agreement to extend the Saudi oil pipeline through Hadramaut. However, Al-Beidh's defeat has made the Saudi support vanishing, given the international community's unanimous attitude for Yemen's unity (Kotsinoveski, January 2008, P. 82-83).

\section{Vil. The Yemeni Unity Path after (1994) WAR}

After the (1994) war defeat of the socialist party, which represented the south divide in the political formula after the unity, President Saleh regime began to practice the power alone all over Yemen and began to rule the south within arrangements which he carefully put to allow him to control the south directly and prevent any future secessionist movement. The political and security institutions in the south were dismantled, upon these arrangements and affiliated to the north divide. Some personnel belonging to these institutions, who accepted to continue to work in northern ones, were appointed, while others retired or became unemployed.

On the political level, President Saleh appointed some of his southern allies, especially previous followers of President Ali Nasser Mohammad, in limited sovereign positions to show, through them, the southerners' representation in the state. So they inherited governmental posts, granted to the southerners after the unity. However, they didn't enjoy the same powers as their predecessors. The southerner officials after the unification and even after the (1994) war were considering themselves as partners in the power. In contrast, the new followers were subject to President Saleh's instructions and indebted to him for these posts, with limited authorities. The post of Vice President, granted by Saleh to Adbrabuh Mansour Hadi, was not but a formal one practically because he didn't' have significant authorities in the state when he assumed power until the revolution erupted against Saleh.

The (1994) war and its aftermath upon the political balance have led the Yemeni unity to liaise with the Northern Central State. This was followed by a delay of holding the local elections and a delay of its law until the year (2000). Also, the decisions and recommendations of the four annual conferences of the local councils remained ineffective, as the General People's Congress, the ruling party of the north, took three-quarters of the parliament seats in (2003). So this has deepened the power's centrality in favor of the north and impeded a viable political multi-party system in the north and south, as President Saleh increased his influence and that of his followers through the Shura Council, the upper house of parliament, which became cooperation, polarization and recruitment instrument for the north politicians and anti-socialist party elite in the south. As some south leaders kept their influence in the unity state, the north leaders continued to assume the higher posts (Glosemayer, January 2008, P. 115-117) so 
the southerners became desperate for this unity and demanded self-determination and abolition of the unification (Al-Maktary, P. 38) then the peaceful southern Hirak (Movement) which calls for secession have appeared in (2007).

The southern governorates came under direct central rule of the northerners or Saleh advocate southerners. When Hirak appeared, President Saleh tried to alleviate the centralism in the southern regions, through granting an increasing number of southerners administrative posts in these governorates, under the pretext of expanding the autonomous rule, so, all governors in the south were southerners.

Furthermore, an increasing number of southern armed forces personnel, who were marginalized after the (1994) war, were affiliated with the state's military and security apparatus. Also some southerners were granted some political posts in the government and state intuitions.

In return, President Saleh confronted the southern movement (Hirak) by using the security and military forces, he arrested many of its leaders and silenced the demonstrations organized by Hirak to contain this secessionist movement. However, these means were not enough to stop the Hirak activity.

The political crisis escalated in (2009) when the opposition (Joint Meeting) parties adopted a political view that the dilemma in Yemen is due to the "individual, family ruling and fanatic centralism" (Al-Maktary, P. 39), so there was monopoly to the authority and wealth. Therefore it is necessary to change the state to become a federal union and to transfer the power peacefully. The economic conditions have deteriorated, followed by the Yemeni young people's revolution during the "Arab Spring", as they demanded President Saleh to give up the power in (2011). However, he confirmed to them that he was the unity maker, protector, and its safety valve.

Some independent revolutionary young people demanded to change the state to become a federal state. In contrast, the UN Security Council resolution No. (2014) for the year (2011) confirmed the integrity of the Yemeni territory. The Gulf initiative has also confirmed this unity, adding that among the missions of reconciliatory President (Abdrabouh Mansour Hadi) (1945-) and the Government of National Accord is the issue of the state and political system structure. So the matter came to light again at the national dialogue conference.

\section{Vili. President Hadi's Effect Upon THE UNITY}

The southern political components interact with the youth revolution in February (2011) was limited, while southern activists held a conference in Cairo in November (2011) during which they demanded the right of self-determination for the south and to reformulate the unity on a form of a federal with two regions for (5) years, after which referendum shall be take place for the southerners to determine their future.

Therefore the south obtained half number of members of the comprehensive National Dialogue Conference, which issued its outcome, through unanimously approved decisions in favor of the multiprovince decentralized state with full power autonomous rule in July (2013). However, the southern movement (Hirak) demanded a federal state after a transitional period whereby the south population shall determine their national future, identity and their country.

The National Dialogue Conference couldn't determine the number of the federal state regions. So, authorized by the Conference, President Hadi formed an ad hoc committee which issued its decision two weeks late in Feb. (2014) to divide Yemen, into (6) regions. The regions were different about the population, area, and resources, so the socialist party from the south and Shiite Zaidi Ansar Allah (The Houthis) from the north have opposed such division.

The draft of Yemeni constitution project confirmed the form of Yemen State on 15/01/2015 in Article (1) as follows "The federal Republic of Yemen is a federal, civil and democratic state and the Presidential System, is composed of a President and Vice President, elected in one list for (5) years, provided that they should not originate from one region, with a federal government and legislative power of two councils, the parliament, consisted of (260) members and the federal council, consisted of (84) members, with each region being represented by (12) elected members according to the relative list system.

Many parties, including President Saleh, saw President Hadi, from Abyan in the south, as the model person to succeed President Saleh upon the Gulf initiative, because he is the Vice President and affiliates to the ruling General People's Congress Party in the north. Some have considered that Hadi is appropriate to run the political dialogue stipulated in the Gulf initiative, because Hadi, who came from outside the traditional influence and force centers that ruled Yemen, is most appropriate for this mission, as he didn't show any political aspiration.

Many people, especially those who participated in the revolution against President Saleh, thought that the reason for the secessionist calls was mismanagement and corruption of the Saleh regime and that Saleh exit and the arrival of a president from the south would lessen the southerners sense of injustice and marginalization, so the secessionist trend would decline when a president from the south assumes the power.

The most significant impact after Hadi's assumption to power was to work to change the $22^{\text {nd }}$ of May unity formula, so he began to implement this gradually and indirectly after becoming President, under 
the pretext of reform and through the national dialogue conference. As President Hadi was from the south, he shares the southern elite of being minority after the unity due to the difference of population number in favor of the northerners with a ratio of nearly (1:5), so this would grant the northerners permanent control of power and render the southerners as a minority, as per the merger unity formula of (1990) which didn't give the southern governorates any special status.

With Hadi's arrival to power, the southerners, especially the socialist party leaders, planned to change the unity formula through the national dialogue conference, which was the appropriate milieu to pass a new formulation. The southerners have also benefited from Saleh rule system divisions due to the revolution against his regime in (2011), mostly formed by northern forces, including the army leaders, tribe leaders, religious people, business people and heads of the bureaucratic system.

The southerners, aided by President Hadi, worked so that President Sleh's rule system would remain in a state of division and conflict, and prevent any reconciliation with each other.

Hadi deviated from the conciliatory President formula, as stipulated at the Gulf initiative, and began to conclude alliances with President Saleh's political opponents, including General Ali Mohsen Al-Ahmar, Hashd tribe leaders, and the Islamic congregation for reform party to reinforce his political status and weaken previous President Saleh followers.

He alleviated the political and security restraints against the southern movement (Al-Hirak) activity and released its detainees, so the secessionists have increased their activity in the south, and the number of those supporting the secession has also increased in the south generally, as such calls were common in the main cities, especially Aden. The secessionists began to publish newspapers and created electronic sites to promote the secession and refuse the unity. These steps occurred within the frame of the (2011) revolution under the pretext of alleviating injustice against the southerners to assimilate them in the Yemeni State.

President Hadi's aim was to promote the secessionist movement in the south to press the Saleh rule system, the northerners in general, and the international community, which was supervising Yemen's political transfer process to accept to amend the $22^{\text {nd }}$ May unity formula between two options, either secession or federation. This matter has led the national dialogue conference to pass a proposal whereby the southerners would obtain half of participants in the conference, to consider the southern issue as the main one before the dialogue and to promote federalism as a solution to Yemen's problems.

President Hadi has exploited the protests in the south to reinforce his political status and created southern entities that support him under the name of the movement (Al-Hirak) under the pretext of weakening the secessionists's power. He also appointed southerners who support him, in key positions and posts, especially in the army and security, under the pretext of assimilating the southerners and make them nearer to the federal solution.

President Hadi also strengthened the Houthis in the north to weaken the Saleh rule system and depend upon them as a northern ally. On the political level, the Houthis were granted several representatives at the dialogue conference, than their political size. He also aided them to extend, on a military and political level, outside their control areas of Sa'dah Governorate. Hadi facilitated Houthis control over Amran Governorate and extended to Sana!.

It seems that the Houthis, who allied with the southerner secessionists, have deepened the intensity of sectarian conflict and civil war in Yemen (Al-Khadri, Jan. 2014).

\section{iX. The National Dialogue Conference AND ITS EFFECTS ON THE UNITY}

The Gulf initiative stipulated a national dialogue that includes all Yemeni political powers to solve the problems that led to the revolution against president Saleh's regime. As preparations for the conference intensified, the allegedly southern matter and Sa'dah issue were inserted at the top issues to be discussed by the transitional President Hadi, the UN delegate Jamal Bin Amr and a big part of what is called the revolution forces, at the top of which was the socialist party, defeated during (1994) war, they claimed that solving the southern issue was the key to solve the other problems of Yemen and that no solution would succeed until the federal system becomes a reality in the country.

The main aim of the national dialogue was to adopt the federal system, under the pretext of dismantling the rule system, which was dominating the power during President Saleh's rule. The conflict has continued inside the conference over the form and nature of such federation about to the number of regions and the south status in the federal state. President Hadi and his followers present at the conference had the role in managing the dialogue.

During the conference sessions, the federation became a focal point within two trends; the first calls for a state formed of two regions, northern and southern, as this way expressed by the socialist party and head of the (Al-Hirak) Mohammad Ali Ahmad- The $2^{\text {nd }}$ trend was to adopt federation based upon a several regions, presented by the other components, at the top of which was the congregation for reform party and the people's congress party.

Seeking to settle the conflict for his favor, President Hadi decided to expel the head of the Al-Hirak component and the other members who supported him 
and replaced them with his followers. The number of regions was postponed and entrusted to an ad hoc committee formed by him after the end of the conference. The federation was approved of (6) provinces, two of which are in the south and the other four in the north.

The conference also adopted a document, in addition to the federation, submitted by UN envoy Jamal Bin Amr over the southern issue, including special privileges to the southerners in the state, the most important of which was granting them half of the political posts in the federal authority, within the three powers, the executive, legislative and judiciary and the right to annul any constitutional or legal amendments touching the "south higher interests".

Despite all these privileges granted to the southerners, they were not generally welcome in the south. They were refused by those calling for total secession and those calling for a federation of two regions. The result was that the dialogue conference did little to change the general trend in the south.

\section{Sana' Fall at the Hand of the HOUTHIS AND ItS ReFleCtion UpON THE UNITY}

The political and military developments increased soon after the dialogue conference, as the Houthis refused to divide the state into (6) regions. So, the conflict escalated between the Houthis, secretly, allied with the previous President Saleh and the conciliatory political authority, represented by President Hadi and his group.

The Houthis managed to extend beyond their normal influence area in Sa'dah Governorate, until they besieged the capital Sana' and occupied it on 21/09/2014. They succeeded, through secret alliances and understandings with more than one party, some of which linked to the left movements, such as the socialist party and President Hadi, who supported the Houthis to deviate the state institutions, especially the army, to achieve military victories over their opponents, mostly from the congregation for reform party, with its military and tribal wings (Al- Jbarat, 2017).

Hadi's position to support the Houthis came out of his desire to consolidate his power and implement his aim to dismantle President Saleh's rule system. So, President Hadi's interests and goals were consistent with those of the Houthis when the latter controlled Sana' and most North regions. Many southerners thought that the Houthis would be satisfied with the north to deal with them differently, as previously stated. The Houthis attitude regarding the unity and southern issue, before controlling Sana' was intentionally ambiguous, as they used to talk about the injustice of the southerners and their right to resist it and that they support them to achieve their interests. There are also other attitudes, which gave a hint to the southerners that the Houthis are different from President Saleh's rule system. The Iranian influence was a guarantee to the southerners and their interests. They were the supporters of the separatist southerners and supporters of the Houthis in the north (Al-Jbarat, 2017).

The Houthis, however, gave up their ambiguous promises to the southerners, for many reasons, moved their armed forces and controlled Aden. President Hadi was hiding, there so he fled once again to Sultanate of Oman. After that, the regional powers, especially Saudi Arabia and the United Arab Emirates formed the Arab Alliance to support the legitimate Yemeni authority, represented by President Hadi to counter the Zaidi Shiite Houthis, contrary to the Previous Saudi attitude which supported the Zaidi imamate and its political system in its capital Sana' and Ta'izz, under the pretext that Saudi Arabia was confronting another regional power, i.e., Iran. The relation between the Houthis and southerners reached new era and the Yemeni unity has entered to a new path.

\section{The War Consequences over Yemeni UNITY}

The southerners in general and the secessionists in particular, have viewed the foreign military intervention of the Arab Alliance, which began on $26 / 03 / 2015$, as a golden opportunity to achieve their aspiration of independence and to get rid of the north domination. In this regard, President Hadi's goals were consistent with those of the separatist southerners to exploit the war to eliminate Houthis security and military presence in the south, so the "South Liberation" has become a priority in the military operations. The justification was pushing the Houthis out of the south as the first necessary step to defeat and eliminate them, given that the south, and Aden in particular, would become a center for Yemeni State institutions and to launch the operations to hit the Houthis in the other regions.

Therefore, the air force and military support by the Arab Alliance to the southerners, was used to hit the Yemeni armed forces and security institutions, as being pro-Houthis and pro-previous President Saleh. There were no plans to assimilate or merge these forces to support President Hadi, as a defender of the legitimacy to empty the south from any military presence of the northern Houthis this time.

The southern resistance and national army were established and supported during the war, mostly southerners. The first beneficiary was the southern forces, which demand secession, as they set up a nucleus army, security and administrative institutions, supported by the Arab Alliance countries, especially the UAE, which took charge of the southern areas and formed military and security units under its command, 
away from President Hadi legitimate power and his Government.

When the Houthi and Saleh forces retreated out of the south, President Hadi and his southern political opponents competed to control the southern areas. President Hadi began to form Presidential protection brigades, led by his son and the security force (Previously the central security), as most of them were from Abyan, where Hadi was born, and Shabwah, which supports him. His opponents have, with UAE support, formed military brigades, mostly organized from Lahij and Al-Dhale Governorates.

President Hadi and his opponents have, after the $1^{\text {st }}$ stage of the south liberation, attempted to conclude an understanding to govern these areas, so he appointed the separatist leaders in administrative and political posts in the south and legitimate government. However, the conflict escalated between them, so he expelled them, and they declared to form the "Southern transitional council", which demands south secession, with support from UAE. So, a new state of conflicts and competition occurred between Hadi and his opponents, the most dangerous of which was the military clash between both sides at the end of Jan. (2018), which resulted in defeating Hadi's forces, as his opponents controlled most of Aden areas.

The Saudi and UAE's regional role has been prevented by public separatist steps in Yemen to keep President Hadi's legitimate power and their legitimate intervention in Yemen.

\section{Xil. Southern Elite's Attitudes of}

\section{THE UNITY}

\section{Current demanding dissociation}

This current was formed during the (1994) war when the General Secretary of the socialist party and exvice President Ali Salem Al-Beidh called for south secession and reviving the previous southern state under the pretext that the north didn't adhere to the accord of the unity state.

After the southerners' defeat in the war, the public secession calls had regressed until the year (2007) when the Hirak appeared with legal demands peacefully. In (2009) President Al-Beidh demanded disassociation, so this current activity increased in the southern areas, despite security and military harassment by President Saleh.

This influence of the prevailing currents, supported by Iran and tolerated by President Hadi Government had increased when Saleh abandoned the power-After the (2015) war, they became part of the military and political resistance against the Houthis and President Saleh in the south, so the allied forces aided them with Houthis defeat. As they withdrew out of the southern areas, these current supporters became the main political and armed force in the south, especially
Aden and adjacent governorates because most security and military forces which controlled these areas belong to the current supporters.

When President Hadi expelled their leaders from the governmental posts, they formed the (southern transitional council) with an authorization through a demonstration in Aden city on 04/05/2017. The foundation statement mentioned the council's goals and programs, i.e., the disassociation and to return the status quo as before the unity.

Aden ex-governor Eidroos Al-Zobaidi led this current, a southerner military leader who militarily resisted President Saleh under President Al-Beidh's leadership. Central and local bodies were formed for the transitional council in all southern governorates, without directly assuming the power in the name of the council in these governorates.

The UAE has supported the council locally and externally and financed its activities and military forces. However, it didn't announce the south secession or establishment of an alternative power other than President Hadi, even though, it practically doesn't recognize the state legitimacy, Presided by Hadi, and calls it the Yemeni occupation state. It also refuses to raise its flag in the southern governorates and uses that of the Previous State before the unity.

It supports Hasan Ahmad Baoom group, a struggler from south Yemen who affiliated to the ProArab front, leader of Al-Mukalla revolution against the unity and supported by Iran and some southern entities representing the southern movement (Al-Hirak), including those close to or aided by President Hadi.

\section{Xiil. People Demanding Federation of Two Regions}

The most important of those calling for such demand is the Cairo conference group, held in Nov. (2011), as it announced its claim of a federal state with two regions for a maximum period of (5) years, a referendum would be a solution for the southerners to determine their destiny, either unity or secession. This current's leader is Ali Naser Mohammad, the ex-south Yemen President and Haider Abu Bakr Al- Attas, first Prime Minister of the unity government. Similar demands were raised by the socialist party and southern Hirak at the national dialogue conferences.

\section{XiV. People Demanding Federation of a Number of Regions}

President Hadi announced that Yemen is a federal state of (6) regions, as this was the nearest formula to his attitudes and that of some other political parties, especially the congregation for reform party and some General People's congress wings, as they opposed the idea of a two- region federation, which they believe would lead to secession. They proposed to 
divide the south into the eastern and western regions, but this didn't obtain approval. The 6 -region idea was taken for granted, according to President Hadi, there was an attempt was made to impose it without making any constitutional or legal amendments.

\section{Unity Aftermath Scenarios}

The Yemeni Republic has, as a state, become a failed and divided state, as the north western part is under the control of the Houthis who didn't obtain any formal recognition of their power or sovereignty, in contrast Saudi Arabia and UAE have practically become a trustee over Yemen's regions which are out of Houthis control, with authorization by President Hadi who couldn't establish any actual authority in these regions, or real and effective state institutions in the temporary capital, Aden.

Such matter would mean the absence of legitimate power in Yemen and a state of mutual dependency between President Hadi, Saudi Arabia and UAE to continue their influence in Yemen.

The war continuation in Yemen has become a real dilemma because the military force cannot settle it. The humanitarian and economic situation is fragile and human catastrophe, leading to sub-alliances and subidentities, based upon different sects, tribal, sectarian, and fanatic grounds which threatened the unity state entity.

The Riyadh agreement in Nov.(2019) achieved two purposes firstly, stopping the military confrontations between the southern transitional council, which demands secession, supported by the UAE, and President Hadi Forces, as he represents the unity state legitimacy.

Secondly, calming the differences between Saudi Arabia, UAE, and their allies in Yemen to reproduce Saudi strategy in Yemen in such a manner as to contain the southern transitional council forces within the legitimate unity state forces (Ramadan, 27 No. 2020). According to these circumstances, the unity's future can only occur within the following hypothetical scenarios:

\section{a) The first scenario: The secession}

To achieve such a scenario, two means should be available, firstly is the accord between the northern and southern parties to terminate the merger unity and return to the previous status quo. Legally, such arrangement requires changing or amending the current constitution to allow the ruling power to grant the southerners self-determination right. However, given Yemen's actual and unknown future, nobody can imagine such a thing to occur, so the secession through internal accord seems impossible.

Secondly, the secession could occur by force and imposing the fait accompli. This matter would require a southern force capable to confirm its control over all southern areas or the least the strategic ones, with self-efforts and external support. Given Yemen's actual situation, no such a force exists, because the current separatists are scattered, cannot issue a decision on their own, and subject to foreign forces, particularly the UAE which can not sponsor or impose the separatist project by force, as such thing is contradictory with the international law which refuses the unilateral secession and violates Yemen-related UN security council resolutions which confirm Yemen's unity and integrity. Furthermore, the UAE can't do such a thing unless approved by Saudi Arabia as secession does not serve its interest, at least currently. A secessionist entity in the south contradicts its justification to intervene in Yemen and the authorization granted to it by the President of Yemen the Republic. This matter would also consolidate Houthis rule in the north, strengthen their position and increase many Yemenis support to them, especially in the north. They have long borders with Saudi Arabia and can not be controlled by the later whether in peace or war. So this scenario is difficult to materialize.

\section{b) The Second scenario: Two-region federation}

This scenario requires conditions similar to the previous one. Brining the Yemeni state back to stability would require some quiet and stable period to agree upon constitutional amendments to allow Yemen's division and re-drawing of the unity state form. It would also require understandings among political players to affect them, and this is currently not possible, given that they entered into military conflict with its reflections upon the social reality. The Houthis, who control most Yemeni territories, are a political and sectarian organization that doesn't accept or believe in a political multi-system or participation in the democratic process (Al-Jbarat 2017).

\section{c) The third scenario: Six-region federation}

This matter seems possible, according to many Yemenis, because it is an outcome of the national dialogue conference and became part of the constitution project, expected to be adopted. To achieve such a scenario, the Houthis should sustain heavy losses by a military force loyal to President Hadi, the initiator of such a project, then the constitution would be adopted through a referendum with local and presidential legislative elections as per the timetable put in the proposed constitution project.

Such condition is inexistent, given that most forces fighting the Houthis, in more than one front, use President Hadi as a legal umbrella for its action, In contrast, they don't follow him and not loyal to him, as there are military and Para-military forces belonging to parties, as it is the case for those fighting at Ma'rab and Al-Jouf front because they belong to the congregation for reform party, religious parties and terrorist organizations and the same can be said to the other areas. 
A decisive victory over the Houthis, if achieved, would be made by force not belonging to President Hadi, meaning that he will not be able to have a political leadership or issue directions to serve his interests, especially about to the 6-region project.

The other matter which would materialize such scenario is Houthis acceptance to govern Azal (Sana' and surrounding area) with amendments to such region's borders, then to enter into a geographic sharing process, whereby the congregation for reform party would obtain Saba' region (Ma'rab, Al-Jouf, Al-Beidha). In contrast, the southerner secessionists would gain the southern provinces. This matter means that Yemen may be become divided into several mini-states, with entities conflicting with each other, rather than establishing a federal state, as publicized by the pro- 6 region federal state.

\section{d) The fourth scenario: The merger unity}

Even though such a scenario has no longer been on the table since the national dialogue conference and approval of the 6-region project, an analysis of the situation in Yemen indicates that it would not become stable and return to the unified central country unless through a central state capable of defeating the separatist forces, the Houthis and fundamental parties, such as the congregation for reform party, the Salafists, Al-Qaida etc., and to reproduce the unified Yemeni State.

To materialize such a scenario, the regional and international parties should change their policy in Yemen to reach reconciliation for a peaceful solution to support such project in the different fields, especially Yemen is witnessing a collapse in its structure, institutions, and control over the various territories for the benefit of tribal, sects or sectarian rebellions. It has lost sovereignty over its territory and struggles to obtain the life necessities, water supplies, and oil which is its earnings source. Its agricultural and fish production is weak while the population suffers from poverty.

\section{The Conclusion}

Yemen today seems a failed state whose military and institutional structure is a focus for many forces on the Yemeni territories, the most distinguished of which is the Shiite Zaidi Houthis in the north who keep more than half of Yemeni deep state institutions with military and paramilitary forces capable of countering the other Yemeni, Arab Alliance and southern transitional council forces all altogether. The southern transitional council controls areas of the south and has military and paramilitary forces, but it lacks actual loyal institutions. It receives support by the UAE. The remains of the legitimate unity state, represented by the Hadi Government, mostly in exile and mainly in Saudi Arabia. It controls different areas in Yemen and tries to the transfer the unity state institutions to the south and central parts of Yemen. It run control the state institutions in the north, but it has military and Paramilitary forces that sometimes control their movements. However, it doesn't have a unified and agreed- upon plan to expand its control over the rest of Yemen. It cannot constitute an influence to remain in existence, given the current circumstances, despite the Saudi military and financial support.

The Riyadh Agreement in (2019) constituted a functional sharing for Saudi Arabia and UAE to control Yemen, so this is a historical turning point of the influencing regional countries in Yemen and their public confirmation over contradicting roles and interests, which pave the path for different attitudes among the Arab Alliance countries about the Yemeni issue and the effect of the international approaches.

The Agreement has contributed to repositioning the military forces of the southern transitional council and Arab Alliance, so that the forces balance will change in the light of success or failure of such step and the military forces in the ground.

Therefore, Yemen seems open to all options, since the Riyadh Agreement and the updated attitudes of the regional and international parties towards Yemen and the military confrontation results in and around Yemen, will determine the form and future of the Yemeni unity state within the framework of above-mentioned scenarios.

\section{Sources And References}

\section{Arabic and Arabised}

1. The Yemeni encyclopedia, Jan. (2003) four volumes, Al-Afif cultural establishment, Sana', Republic of Yemen, Arab unity studies center, Beirut, Republic of Lebanon.

2. Al-Qasemi, Khalid Bin Mohammad, 1987, the Yemeni unity present and future, Beirut, Lebanon.

3. Abu Taleb, Hasan, 1994, the Yemeni unity, studies in transformation processes from fragmentation to the unity, Arab unity studies center, Beirut.

4. Ibn Thabet, Ali, the Yemeni unity, excerpts from history and current missions.

5. Al-lkab, Abdelwihab Adem, 2010, the Yemeni unity, documentary study of Yemen's contemporary history from Imam Ali to Yemen's contemporary history, Raslan Est. for Publication and distribution, Damascus.

6. Al-Sewidi, Jamal Sanad, edited, 1996, Yemen War 1994, the reasons and consequences, a group of researchers, emirates center for studies and strategic research, Abu Dhabi, UAE.

7. Al-Salahi, Fouad Abdeljalil, edited, Nov. 2012, a group of authors, the Yemeni revolution, background and perspectives, Arab Center for research and policy studies, Doha, Qatar. 
8. Al-Jbarat, Mahmoud Mohammad, 2014, Studies in Yemen's Contemporary History, Ward House, Amman, Jordan.

9. Arab future symposium, 1991, one year after the Yemeni unity, Arab future, volume 14, title 147, P. 102-124.

10. Abu Ismail, Umaima, 1991, Yemeni unity and colonial conspiracy, Al- Wihda, volume 8, title 85, P. 163-169.

11. Marhon, Abdeljalil, 1992, internal and external environment of the Yemeni unity, middle east affairs, title 9, P. 9-34.

12. Carter, Mark, 1992, Yemeni unity and Saudi security, strategic studies, title 31, P. 1-30.

13. Al-Asbahi, Ahmad Mohammad, 2000, Yemeni unity, promising Arab model on the eve of $21^{\text {st }}$ century, Middle East studies, volume 4, P. 43- 77.

14. Al-Sharjabi, Abdelbari Ahmad No'man, 1999, the economic effects of consolidating the Yemeni unity, initial study social studies magazine, title 5, P. 155186.

15. Abu Taleb, Hasan, Jan. 1994, Yemeni unity, studies in transformation processes from fragmentation to unity, Arab unity studies center, $1^{\text {st }}$ edition, Beirut.

16. Botchek, Christopher, Sep. 2009, Yemen, how to avoid increasing collapse? Correlated economic, demographic and security challenges threatening Yemen, Karuiji papers, 102.

17. Al-Qasemi, Khaled Bin Mohammed, 1987, Yemeni unity, present and future, Al-Hilal house and library for typing and publication, Beirut.

18. Al-Shahari, Mohammad Ali, 1994, Yemeni unity, left opportunists and Yemeni socialist party, Al-Farabi house, Beirut.

19. Jirasimov, oleg, June and July 1982, creation of opposition movement in north Yemen, translated by Ahmad Hasan Saeed, Yemeni studies magazine, Yemeni studies and research center, Sana' edition 8 , and 9 .

20. Hassan, Abdelkawi, 2014, Islamic movement in Yemen, study in thought and practice, Yemeni reformation assembly as model, Arab future, year 37, No. 427, Sep. 2014, P. 44-55.

21. Park, G. Lodder, 1927, Excavation of Petrol in the red sea, translated by Balkis Al-Hadrani, US document, Yemeni studies, seasonal magazine issued by Yemeni studies and research center, Sana', Arab Republic of Yemen, No. 22, Nov. -Dec. 1985.

22. Abdallah, Thana, 2001, the state and social force in the Arab world, reaction and conflict relations, Arab unity studies center, Beirut, $1^{\text {st }}$ edition, June 2001.

23. Abdelhaleem Iman, July 2014, federation test, regions future in Yemen, International politics, No. 197, volume 49, P. 124-129.
24. Al-Sharjabi, Adel Mojahed, March 2014, document of comprehensive national dialogue in Yemen, Arab policies, No. 7, P. 5-12.

25. AlSharjabi, Adel Mojahed, 2011, state failure and collapse, Yemen case, state crisis in the Arab world, research and discussions of the thinking symposium, organized by Arab unity studies center, in cooperation with Karneji center for Middle East and Arab Society for political sciences, $1^{\text {st }}$ edition, Beirut, P. 125-195.

26. Abu Zeid, Ahmad Mahmoud, march 2018, Political stability of the Arab Gulf Cooperation Council towards immigration challenge and population imbalance, Arab policies magazine, No. 31, 23-46.

27. Al-Arshi, Yahia bin Hussein, 2003, Yemeni unity article, Yemeni encyclopedia, volume 4, P. 31263148.

28. Al-Maktari, Adnan Yasin, July 2018, federal state option in Yemen, backgrounds, justifications and transfer challenges, Arab policies, No. 33, P. 34-48.

29. Bonfoi, Lorent, 2014, to what extent is salafism trans-national in Yemen? International salafism, contemporary salafism movements in a changing world, edited by Roll Meer, translated by Ahmad Mahmoud Toba, Arab research network, Beirut, $1^{\text {st }}$ edition.

30. Al-Khadri, Anwar bin Qasem, Jan. 2014, sectarianism and civil war in Yemen, Arab policies, No. 6, P. 64-71.

31. Sha'than, Ali, Jan.2015, external influences in Yemeni controversy, Arab Policies, No. 12, P. 104-111.

32. Al-Modi, Abdelnaser, winter 2015, Yemeni crisis, middle east studies, year 2018, No. 70, P. 13.

33. Al-Salahi, Fouad Abdeljalil, edited, Nov. 2012, Yemeni revolution, background and perspectives, Arab center from research and policies study, $1^{\text {st }}$ edition, Beirut.

34. Al-Jbarat, Mahmoud Miohammad, 2017, political Islam and multi- system, Zaidism in Yemen as a model, historical perspective, the $4^{\text {th }}$ international conference of progressive thought in contemporary Arab and Islamic studies, Indonesian, Jakarta University.

35. Al-Jbarat, Mahmoud Mohammad, 2014, studies in Yemen contemporary history, Jordan, Ward publication house.

36. Halidany, Farid, 2008, political conflict in Arabia, translated by Mohammad Al-Romaihi, Al-Saki house.

37. Philips, Sarah, 2007, evaluating the political reform in Yemen, Karniji papers, No. 80.

38. Kotsinoviski, Tomas, Yemeni foreign policy since the unity and Saudi role, P. 75-95, the book contemporary Yemen, edited by Lovo, Reemi, 
Frandk Maramid and Hong stanikh, 2008, translated by Ali Mohamamd Zaid, Euphrates publication and distribution, Beirut, Lebanon.

39. Marmia, Frank, 2008, Yemen: Partitioned historical heritage, P. 9-43, the book: contemporary Yemen, Lovo, Reemi, Frank Marmia and Hogo Stanikh, 2008, translated by Ali Mohammad Zaid, Euphrates publication and distribution, Beirut, Lebanon.

40. Rojeh, Berard "Yemen between 1990-1994, Failure of political charter logic" P. (123-158) the book the book contemporary Yemen, edited by Lovo, Reemi, Frandk Maramid and Hong stanikh, 2008, translated by Ali Mohamamd Zaid, Euphrates publication and distribution, Beirut, Lebanon.

41. Brik, Jabrail foom, Zaidism without imam, reconsidering the doctrine and religious teachings, P. 191- 219, the book: contemporary Yemen, Lovo, Reemi, Frank Marmia Hogo Stanikh, 2008, translated by Ali Mohammad Zaid, Euphrates publication and distribution.

\section{The English}

1. Fisher, John, July 1997; "The Safety of Our Indian Empire; Lord Curzon and British Predominance in the Arabian Peninsula", 1919.

2. Middle Eastern Studies. Vol. 33, No. 3, pp.494-52.

3. Gause III, F. Gregory, Winter1988, Yemeni Unity: past and future: The Middle East Journal, Vol. 42, No. 1.

4. Browen, William R., Autumm 1963, "The Yemeni Dilemma: The Middle East Journal", Vol. 17, Number 4, P. 249-367.

5. Sanger, Richard Harlakenden, 1970, The Arabian Peninsula, Freeport, New York.

6. Hoskins, Helford L, Winter 1987, "Background of the British position in Araia", The Middle East Journal, Vol. 41, No. 1, P. 137-147.

7. Al-Jbarat, Mahmoud, "Yemen Crises: Historical Roots and solution spheres", Global Journal of Huamn Social SD, History and Archeology Anthropology, USA, Vol. 16, Issue 3, Version 1, P. 1-8.

8. Al-Akhali, Rafat; May 2014, The Challenge of Federalism in Yemen, Atlantic Council, Issue brief.

9. Sharp, Jeremy, M., February 11, 2015", Yemen: Background and U.S Relatins", Congressional Research Service, 7-5700, www.crs.gov

10. Erica Gaston, February, 2014 "Process Lessons Learned in Yemen's National Dialogue: Special report". United States institute of peace, www.usip.org

11. Orkaby, Asher Aviad, 2014. the International History of the Yemen Civil War, 1962-1968. Doctoral dissertation, Harvard University.

12. Ramadan, Hussam 27 Nov. 2020, "The Riyadh Agreement one year on", Snaa Center for Strategic studies.

E-Sites 